Revista Eletrônica Geografar, Curitiba, v. 2, Resumos do VI Seminário Interno de Pós-Graduação em Geografia, p. 60-60. Junho/2007

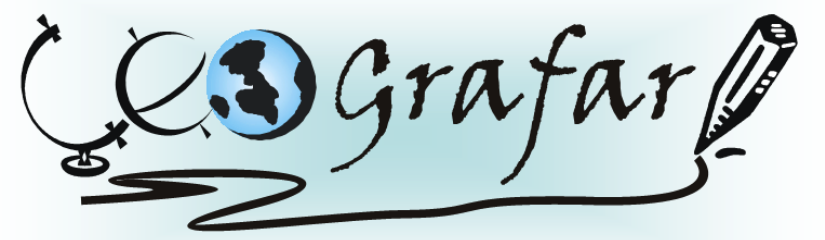

Revista Eletrônica do Programa de Pós-Graduação em Geografia - UFPR

\title{
ANÁLISE DO REGIME HIDROLÓGICO E SEDIMENTAR DA BACIA DO RIO IAPÓ
}

\author{
POLLYANA CROCETTA BIAZIN ${ }^{1}$
}

Os cursos d'água possuem uma importância sob os aspectos geomorfológico, biológico e antrópico, e o homem através de suas diversas atividades relacionadas ao uso e ocupação da bacia pode vir a comprometer a qualidade, manutenção e equilíbrio dos mananciais, dessa forma, o conhecimento do regime hidrológico dos sistemas fluviais passa a ser necessário. A previsão das condições de utilização da água se baseia na hipótese de que os regimes dos cursos de água, observados no passado, se reproduzem no futuro sem alteração. A proposta dessa pesquisa é a de aprofundar o conhecimento referente à bacia do rio Iapó acerca de suas características físicas (sedimentologia, geomorfologia) e geoambientais (uso do solo e dos recursos hídricos de superfície), pois o rio Iapó ainda não foi alvo de pesquisas de cunho científico que contemplasse aspectos de seu regime hidrológico e sedimentar. O comportamento do rio Iapó é bastante variado, passando de um perfil em equilíbrio com diversos meandros em uma ampla planície de inundação na cidade de Castro (Primeiro Planalto), para um rio rejuvenescido quando começa a adentrar a escarpa Devoniana, originando o canyon (Parque Estadual do Guartelá). A delimitação das áreas alagáveis da planície tem uma importância ambiental e econômica, principalmente na porção próxima a cidade de Castro, região que sofre alagamentos. Portanto o entendimento dessa dinâmica também será contemplado nesse estudo. $\mathrm{O}$ conhecimento da dinâmica atual é fundamental para estudos ambientais neste ecossistema, pois permite a análise do comportamento do período de cheias do canal fluvial e sua interrelação com a planície. O objetivo geral dessa pesquisa é estudar a dinâmica sedimentar e o regime de cheias do rio Iapó, buscando conhecer seus processos e suas implicações ambientais.

Palavras-chaves: rio Iapó, regime hidrológico, dinâmica sedimentar.

'Doutoranda em Geografia - UFPR - email: pollybiazin@yahoo.com.br Orientador: LEONARDO JOSÉ CORDEIRO SANTOS 